\title{
The Relationship between Working Capital Management and Profitability of Bumiputera-Controlled Companies in Malaysia
}

\author{
Fairuz Sofia Kaharuddin, Ahmad Rizal Mazlan*
}

UUM Kuala Lumpur, Universiti Utara Malaysia

\begin{abstract}
This study investigated the relationship between working capital management and profitability of 94 listed Bumiputera-controlled companies in Malaysia for 2006 until 2012. The underlying theory is the trade-off theory of working capital and cash conversion cycle, and its components are used as measures for working capital management. Findings of the panel data regression reveal that inventory conversion period and receivable collection period are significantly negatively correlated to profitability. This suggests that the shorter the period, the higher the profitability of Bumiputera-controlled companies tends to be. However, the cash conversion cycle is significantly and positively correlated to profitability, suggesting that the longer the cash conversion period, the higher the profitability. The payable collection period is not significantly correlated to profitability. The findings of this study assert that in general, Bumiputera-controlled companies are relatively less efficient in its working capital management, as far as the comparison to previous related studies is concerned.
\end{abstract}

Keywords: Working capital management, trade-off theory, profitability, Bumiputera-controlled companies, Malaysia

JEL Classification: G32

Paper Type: Research

*Corresponding author: E-mail: arizal@uum.edu.my 


\section{INTRODUCTION}

Working capital management, which is the management of current assets and current liabilities, is a crucial component of any business and has been the focus of many empirical studies. Every business organisation aims to maintain a sufficient level of a current asset, especially the account receivable and inventory. At the same time, a business also aims to control accounts payable in such a way that it can fulfil its short-term commitments on time. In general, working capital is made up of securities, accounts receivable, cash and inventory, while net working capital the difference between current assets and current liabilities. Whenever the amount of current assets is higher compared to current liabilities, the company can meet its obligations easily (Khanqah et al., 2011).

Numerous studies in various countries have examined the relationship between working capital and profitability. Among them are Gill et al. (2010), in the US; Dong \& Su (2010), in Vietnam; Deloof (2003), in Belgium; and Lazaridis and Tryfonidis (2006), in Greece. In general, most of them found that working capital components such as cash conversion cycle is negatively related to profitability, verifying the trade-off theory which states that the longer cash conversion cycle reduces profitability. Several studies in other countries also recorded the negative relationship between those variables were (Saghir et al. 2011; Garcia \& Martinez, 2007; Gul et al. 2013; Mansoori \& Muhammad, 2012; Nimalathasan, 2010; and Ray, 2012).

However, the studies by Gill et al. (2010), Ali (2011), Sharma and Kumar (2011), Ademola (2014), Abuzayed (2012), Baveld (2012), Rimo and Panbunyuen (2010), and Karadagli (2012) show a positive relationship between working capital and profitability. In contrast to the trade-off theory, companies manage to increase profitability with a longer cash conversion cycle, within a tolerable range. In Malaysia, the studies by Mohamad and Saad (2010) and Wasiuzzaman and Arumugam (2013) recorded mixed results with regards to the relationship between working capital components and profitability.

As a developing country aspiring to be a developed country, Malaysia is banking on its public-listed companies (PLCs) to propel the country's gross domestic product (GDP) to record an average annual growth rate of $7 \%$ into the foreseeable future. According to The Star Online report (2015), the number of Bumiputera-controlled companies is 132 or $14.4 \%$ of the PLCs in the Malaysian stock exchange. Therefore, it is important to investigate the role played by Bumiputera-controlled public-listed companies with regards to the working capital management and profitability. This research seeks to determine the relationship between working capital components and profitability of Bumiputeracontrolled PLCs in Malaysia. The findings are expected to provide us with some understanding of the business performance as well as the management efficiency of those companies, and a comparison can be made to other companies. Also, the findings may be a useful input to policymakers in defending or revising specific policies.

Several researchers have previously examined the financial performance of Bumiputera-controlled companies. Marimuthu (2010) reports that the impact of the crisis and post-crisis periods on the performance of Bumiputera-controlled companies throughout 1996 to 2005 is evident, where the companies faced both short run and long run issues due to the financial crisis. Halim et al. (2014) look into the management issues and financial performance of Bumiputera construction firms. The findings show that, in general, the firms have an inadequate amount of capital to finance their projects, generate a small amount of profits, have high debt level, and are less efficient in managing their assets. Additionally, Aminudin (2000) analyses the corporate performance and ownership structure of Bumiputera and non-Bumiputera controlled companies listed on the KLSE from 1993 to the first quarter of 1997, just before the economic downturn. The results suggest that the ownership structure would not impact the performance of the accounting 
profit of companies. In the study by Yatim et al. (2006), it was shown that Bumiputeracontrolled firms have better internal corporate governance practices compared with nonBumiputera firms.

In line with the discussion above, and to the researcher best knowledge, there is hardly any research that examines the relationship between working capital management and profitability of Bumiputera-controlled companies in Malaysia. Therefore, this study intends to address the gap in the literature by examining the relationship of working capital management and profitability of Bumiputera-controlled companies in Malaysia with the following research objectives. Specifically, the relationship between profitability and working capital components, namely, cash conversion cycle, inventory conversion period, receivable conversion period and payable conversion are examined.

\section{LITERATURE REVIEW}

This chapter reviews previous literature on the relationship between working capital management and profitability. In addition, it also frames out several issues about Bumiputera-controlled companies.

\subsection{The trade-off theory}

The trade-off theory is one the main theories which explain about working capital management whereby there is a trade-off between profitability and risk which is associated with the level of current asset and liabilities (Abuzayed, 2012). This is based on earlier work by Smith (1980) which signalled the importance of the trade-offs between the goals of liquidity and profitability. According to Raheman and Nasr (2007), increasing profits at the cost of liquidity can bring serious problems to the firm. Dittmar et al. (2002) indicate that when firms are liquid, they generate huge amount of net working capital which may reduce the level of profitability, and vice-versa, hence the negative relationship between liquidity and profitability.

\subsection{Relationship between profitability and working capital management}

As an indicator of firm performance, profitability is often measured using return on assets (ROA), which is calculated as the ratio of net income to total assets, and also return on equity (ROE), which is calculated as the ratio of net income to total equity. Many researchers have utilised both ROA and ROE as the dependent variable to proxy for the profitability of a firm (Ali, 2011; Bulin et al. 2016; Sin et al. 2017; Wasiuzzaman, 2015; Gill et al. (2010).

Other measurements for profitability include gross operating income (Yunos, et al., 2015), gross operating profit (Deloof, 2003; Lazaridis \& Tryfonidis, 2006; Gill et al., 2010), net operating profit (Usama, 2012; Mathuva, 2010) and return on sales (Ching et al., 2011). However, ROA is the most common variable used for profitability and is thus used in this research as the dependent variable.

\subsection{Working capital management}

Working capital management comprises of the cash conversion cycle, average collection period, inventory turnover in days, net trading cycle, and average payment period of a firm (Raheman et al., 2010). Cash conversion cycle (CCC) is the period between the payment for raw materials by a company and collection of payment from the customer. Based on the trade-off theory, firm profitability should be negatively related with CCC because 
shorter CCC translates into either shorter production time and/or shorter collection period hence the possibility or reducing costs to increase the profit. Table 1 summarises the previous studies which have examined the relationship between WCM and profitability.

Table 1. Overview of previous studies on the relationship between WCM and profitability.

\begin{tabular}{|c|c|c|c|}
\hline Variables & Country & Literature & Findings \\
\hline \multirow{2}{*}{$\begin{array}{l}\text { Cash } \\
\text { Conversion } \\
\text { Cycle (CCC) }\end{array}$} & $\begin{array}{l}\text { Developing } \\
\text { country }\end{array}$ & $\begin{array}{l}\text { Sin et al. (2017): Malaysian listed manufacturing companies } \\
\text { from } 2007-2012\end{array}$ & positive \\
\hline & $\begin{array}{l}\text { Developed } \\
\text { country }\end{array}$ & $\begin{array}{l}\text { Lazaridis and Tryfonidis (2006): companies which were listed } \\
\text { in the Athens Stock Exchange from } 2001-2004\end{array}$ & negative \\
\hline \multirow{2}{*}{$\begin{array}{l}\text { Inventory } \\
\text { Conversion } \\
\text { Period (ICP) }\end{array}$} & $\begin{array}{l}\text { Developing } \\
\text { country }\end{array}$ & $\begin{array}{l}\text { Albdwy et al. (2014): Malaysian Shariah compliance and } \\
\text { non-Shariah compliance listed companies from } 2009 \text { - } 2013\end{array}$ & negative \\
\hline & $\begin{array}{l}\text { Developed } \\
\text { country }\end{array}$ & Deloof (2003): Belgian non-financial firms from 1992 - 1996 & negative \\
\hline \multirow{2}{*}{$\begin{array}{l}\text { Receivable } \\
\text { Collection } \\
\text { Period (RCP) }\end{array}$} & $\begin{array}{l}\text { Developing } \\
\text { country }\end{array}$ & $\begin{array}{l}\text { Wasiuzzaman (2015): Malaysian manufacturing firms from } \\
1999 \text { - } 2008\end{array}$ & negative \\
\hline & $\begin{array}{l}\text { Developed } \\
\text { country }\end{array}$ & $\begin{array}{l}\text { Mansoori and Muhammad (2012): } 92 \text { listed companies in } \\
\text { Singapore from } 2004-2011\end{array}$ & negative \\
\hline \multirow{2}{*}{$\begin{array}{l}\text { Payable } \\
\text { Collection } \\
\text { Period (PCP) }\end{array}$} & $\begin{array}{l}\text { Developing } \\
\text { country }\end{array}$ & $\begin{array}{l}\text { Saghir et al. (2011): } 60 \text { textile firms from Karachi stock } \\
\text { exchange from 2001 - } 2006\end{array}$ & negative \\
\hline & $\begin{array}{l}\text { Developed } \\
\text { country }\end{array}$ & Deloof (2003): Belgian non-financial firms from 1992 - 1996 & negative \\
\hline \multirow{2}{*}{$\begin{array}{l}\text { Size of the } \\
\text { firm (Size) }\end{array}$} & $\begin{array}{l}\text { Developing } \\
\text { country }\end{array}$ & $\begin{array}{l}\text { Yunos et al. (2015): government-linked companies listed in } \\
\text { Bursa Malaysia from } 2003-2014\end{array}$ & positive \\
\hline & $\begin{array}{l}\text { Developed } \\
\text { country }\end{array}$ & $\begin{array}{l}\text { Deloof (2003) - } 1009 \text { Belgian non-financial firms from } 1992 \text { - } \\
1996\end{array}$ & negative \\
\hline \multirow{2}{*}{$\begin{array}{l}\text { Debt Ratio } \\
\text { (DR) }\end{array}$} & $\begin{array}{l}\text { Developing } \\
\text { country }\end{array}$ & $\begin{array}{l}\text { Sin et al. (2017): Malaysian listed manufacturing companies } \\
\text { from } 2007-2012\end{array}$ & negative \\
\hline & $\begin{array}{l}\text { Developed } \\
\text { country }\end{array}$ & $\begin{array}{l}\text { Gill et al. (2011): American service and manufacturing firms } \\
\text { which were listed in New York Stock Exchange from } 2005 \text { - } \\
2007\end{array}$ & positive \\
\hline \multirow{2}{*}{$\begin{array}{l}\text { Sales Growth } \\
\text { (SG) }\end{array}$} & $\begin{array}{l}\text { Developing } \\
\text { country }\end{array}$ & $\begin{array}{l}\text { Sharma and Kumar (2010): } 263 \text { non-financial BSE } 500 \text { firms } \\
\text { listed at the Bombay Stock (BSE) from } 2000 \text { to } 2008\end{array}$ & negative \\
\hline & $\begin{array}{l}\text { Developed } \\
\text { country }\end{array}$ & $\begin{array}{l}\text { Deloof (2003): } 1009 \text { Belgian non-financial firms from } 1992 \text { - } \\
1996\end{array}$ & positive \\
\hline
\end{tabular}

\subsection{Related studies about Bumiputera-controlled companies}

Previous studies on BCCs have examined the issues of corporate performance, ownership structure, corporate governance practices, financing and also IPO performance. Table 2 summarises previous studies which have looked at BCCs.

Table 2. Overview of previous studies on the Bumiputera-controlled companies in Malaysia

\begin{tabular}{|c|c|c|}
\hline Authors & Focus of Study & Findings \\
\hline $\begin{array}{l}\text { Aminudin } \\
(2000)\end{array}$ & $\begin{array}{l}\text { This study looked into the corporate } \\
\text { performance, and ownership structure of } \\
\text { Bumiputera and non-Bumiputera controlled } \\
\text { companies. }\end{array}$ & $\begin{array}{l}\text { Performance of Bumiputera and non- } \\
\text { Bumiputera controlled companies were } \\
\text { equally competitive. }\end{array}$ \\
\hline $\begin{array}{l}\text { Dev et al. } \\
(2006)\end{array}$ & $\begin{array}{l}\text { Explored the IPO prices of Malaysia in the } \\
\text { short run and long run. }\end{array}$ & $\begin{array}{l}\text { Malaysia's IPO prices are lower compared } \\
\text { to IPO in the developing countries. }\end{array}$ \\
\hline $\begin{array}{l}\text { Yatim et al. } \\
(2006)\end{array}$ & $\begin{array}{l}\text { The study looked into the performance of } \\
\text { Bumiputera-controlled companies in the } \\
\text { year } 1986 \text { to } 2001 \text { in paying higher audit } \\
\text { fees due to the weaker governance } \\
\text { practices. }\end{array}$ & $\begin{array}{l}\text { Lower external audit fees are paid by the } \\
\text { Bumiputera-controlled firms since their } \\
\text { internal governance structures are } \\
\text { relatively stronger than the non-Bumiputera } \\
\text { firms. }\end{array}$ \\
\hline
\end{tabular}




\begin{tabular}{lll}
\hline Authors & Focus of Study & Findings \\
\hline $\begin{array}{l}\text { Marimuthu } \\
(2010)\end{array}$ & $\begin{array}{l}\text { Looking into the impacts of crisis and post- } \\
\text { crisis periods which were considered from } \\
1996 \text { to } 2005 \text { of 33 Bumiputera-controlled } \\
\text { companies which were listed on Bursa } \\
\text { Malaysia }\end{array}$ & $\begin{array}{l}\text { Bumiputera-controlled companies } \\
\text { experienced difficulties for both short-term } \\
\text { and long-term due to the financial crisis. }\end{array}$ \\
$\begin{array}{l}\text { Halim et al. } \\
(2014)\end{array}$ & $\begin{array}{l}\text { Investigated the financial performance and } \\
\text { management issues of Bumiputera } \\
\text { construction firms. }\end{array}$ & $\begin{array}{l}\text { The level of capital liquidity of the } \\
\text { contractors on average was lower than the } \\
\text { industry average, received small profits } \\
\text { from construction projects, burdened with } \\
\text { higher debt and was less efficient in }\end{array}$ \\
& & $\begin{array}{l}\text { managing their financial resources or } \\
\text { assets. }\end{array}$ \\
\hline
\end{tabular}

\section{RESEARCH DESIGN AND METHODOLOGY}

A list of 94 Bumiputera-controlled companies was obtained from the book of "Ikon Bumiputera PLC 2014-2015". Data of each company for 2006 until 2015 were collected from DataStream of UKM's library. Analysis of the relationship for working capital management (WCM) and firm profitability was carried out using descriptive statistics, correlation analysis and regression analysis.

For the regression, the dependent variable is a return on asset (ROA) which is a measurement of profitability. ROA was also employed as the dependent variable by Garcia et al. (2007); Mansoori and Muhammad (2012); Anojan et al. (2013); Gul et al. (2013); Yunos et al. (2015); Wasiuzzaman (2015); Bulin et al. (2016) and Sin et al. (2017).

Table 3. Measurement of Variables and Definitions

\begin{tabular}{|c|c|c|}
\hline Variable & Definition & Measurement \\
\hline $\begin{array}{l}\text { Return on Asset } \\
\text { (ROA) }\end{array}$ & $\begin{array}{l}\text { This is a measure of a firm's } \\
\text { profitability. It gauges how efficiently a } \\
\text { firm uses its assets to produce income. }\end{array}$ & $\begin{array}{l}\text { ROA = Net sales (operating profit)/Total } \\
\text { assets (Deloof., (2008;) and Albdwy et } \\
\text { al., (2014)) }\end{array}$ \\
\hline $\begin{array}{l}\text { Inventory Conversion } \\
\text { Period } \\
\text { (ICP) }\end{array}$ & $\begin{array}{l}\text { This is the time (in days) taken } \\
\text { required to convert inventory held in of } \\
\text { the firm into sales }\end{array}$ & $\begin{array}{l}\text { ICP }=(\text { Inventory/Cost of Sales) *365. } \\
\text { (Gul et al., (2013), and Albdwy et al., } \\
(2014)) .\end{array}$ \\
\hline $\begin{array}{l}\text { Receivable Collection } \\
\text { Period } \\
\text { (RCP) }\end{array}$ & $\begin{array}{l}\text { The time spent (in days) for the } \\
\text { collection of cash from customers }\end{array}$ & $\begin{array}{l}\text { RCP = (Trade Receivables/Net Sales) } \\
\text { *365. (Gul et al., (2013;), and Albdwy et } \\
\text { al., (2014)). }\end{array}$ \\
\hline $\begin{array}{l}\text { Payable Collection } \\
\text { Period } \\
(\mathrm{PCP})\end{array}$ & $\begin{array}{l}\text { This refers to the time spent (in } \\
\text { to pay to the suppliers of the fir }\end{array}$ & $\begin{array}{l}\text { PCP = (Trade Payables/Cost of sales) } \\
\text { *365. (Gul et al., (2013;), and Albdwy et } \\
\text { al., (2014)). }\end{array}$ \\
\hline $\begin{array}{l}\text { Cash Conversion } \\
\text { Cycle } \\
\text { (CCC) }\end{array}$ & $\begin{array}{l}\text { This is the period (in days) between } \\
\text { the firm's payment for materials and } \\
\text { collection on its sales }\end{array}$ & $\mathrm{CCC}=\mathrm{ICP}+\mathrm{RCP}-\mathrm{PCP}$ \\
\hline $\begin{array}{l}\text { Firm Size } \\
\text { (SIZE) }\end{array}$ & $\begin{array}{l}\text { The data for total assets are in the } \\
\text { asset classification of a firm's balance } \\
\text { sheet assets }\end{array}$ & $\begin{array}{l}\text { The logarithm of its total assets (Deloof, } \\
\text { 2003; Wasiuzzaman and Arumugam, } \\
\text { (2013); Gul et al., 2013) }\end{array}$ \\
\hline $\begin{array}{l}\text { Sales Growth } \\
\text { (SG) }\end{array}$ & $\begin{array}{l}\text { The variation in its annual sales value } \\
\text { concerning sales of the previous year }\end{array}$ & $\begin{array}{l}\text { [(Sales t - Sales t-1)/Sales t-1] (Deloof, } \\
\text { 2003; Wasiuzzaman and Arumugam } \\
\text { (2013); Gul et al., 2013; Nobanee, 2009) }\end{array}$ \\
\hline $\begin{array}{l}\text { Debt ratio } \\
\text { (DR) }\end{array}$ & $\begin{array}{l}\text { This is the degree to which } \\
\text { a firm is utilising borrowed money }\end{array}$ & $\begin{array}{l}\text { Total debt/total asset (Gul et al., 2013; } \\
\text { Wasiuzzaman and Arumugam, 2013). }\end{array}$ \\
\hline
\end{tabular}

For the independent variables, Cash Conversion Cycle (CCC) and its components are frequently employed to measure the working capital management (Deloof, 2003 and Zariyawati et al., 2009). Many previous studies have shown that CCC had given significant results (Deloof, 2003; Gill et al., 2010; Sharma \& Kumar, 2011; Ali, 2011; Jacob, 2014; 
Bulin et al., 2016 \& Sin et al., 2017). The components of the cash conversion cycle are the inventory conversion period, trade receivable collection period and trade payable collection period. The control variables included in the study are firm size (Deloof, 2003; Sharma \& Kumar, 2011; Yunos et al., 2015), growth (Bottazzi et al., 2001; Deloof, 2003; Cowling, 2004; Jang \& Park, 2011), and leverage (Salim \& Yadav, 2012; Gill et al., 2010; Sin et al. 2017). Firm size is measured by total assets; growth is proxied by sales growth while leverage is measured by debt ratio.

The model specification of this study is adapted from Gul et al. (2013), and Charitou et al. (2010) as follows (from 2006 until 2015):

$$
\text { ROAit }=\beta 0+C C C i t+I C P i t+R C P i t+P C P i t+S I Z E_{i t}+S G_{i t}+D R_{i t}+e_{i t}
$$

\section{ANALYSIS OF RESULTS}

\subsection{Descriptive Statistics}

Based on the descriptive statistics in Table 4, ROA has a mean value of $3.82 \%$ and standard deviation of $14.6 \%$. The mean value of CCC is 154 days with a standard deviation of 218.8 days, indicating a wide variation of CCC among the BCCs. The CCC in this study is longer than that generated by other studies in Malaysia such as Zariyawati et al. (2009) and Zariyawati et al. (2016). This longer period is consistent with the study conducted by Halim et al. (2014), which reveals that, on average, the capital liquidity in Bumiputera companies is lower than the industry average. The average ICP is 156 days, with a standard deviation of 277.49 days. Similar to CCC, the ICP in this study is longer than the ICP reported by other studies in Malaysia such as Albdwy et al. (2014), and Misbah et al. (2015). This may indicate that BCCs are inefficient in managing their inventory.

Table 4. Descriptive Statistics

\begin{tabular}{llllll}
\hline & Minimum & Maximum & Mean & Median & Std. Deviation \\
\hline ROA (\%) & -23.25 & 121.37 & 3.8177 & 2.2344 & 14.59062 \\
CCC & -196.34 & 827.84 & 154.0740 & 104.8102 & 218.83603 \\
ICP & .00 & 1542.20 & 156.0782 & 61.7344 & 277.48897 \\
RCP & 29.07 & 2525.57 & 217.2056 & 139.1880 & 309.09375 \\
PCP & .44 & 2789.94 & 194.6169 & 85.4853 & 412.09326 \\
SIZE & 1.31 & 4.49 & 2.7111 & 2.7148 & .63003 \\
SG $(\%)$ & -17.22 & 449.06 & 20.1994 & 8.0366 & 57.03667 \\
DR $(\%)$ & 9.12 & 333.34 & 51.4968 & 45.9299 & 41.73552 \\
\hline
\end{tabular}

${ }^{*} \mathrm{CCC}, \mathrm{ICP}, \mathrm{RCP}$ and PCP are in days, while SIZE is in LN of Total Assets

The average time spent to pay to the suppliers (PCP) is 195days, with a standard deviation of 412.09. This is longer than PCP generated by other studies in Malaysia conducted by Albdwy et al. (2014), and Misbah et al. (2015). For RCP, the average time spent on the collection of cash from customers is 217.2 days, with a standard deviation of 309.09 . Meanwhile, the mean RCP is 139 days, which is shorter than RCP in Misbah et al. (2015). For control variables, SIZE reports a mean of 2.71 (RM514.16 million), smaller rather than SIZE value generated by other studies in Malaysia like Wasiuzzaman and Arumugam (2013), and Yunos et al. (2015). The average sales growth is $20.2 \%$, with a standard deviation of $57 \%$, indicating a wide variation in sales growth among the BCCs. The average debt ratio is $51.5 \%$ of total assets, with a standard deviation of $41.74 \%$, higher than the debt ratio generated by Zariyawati et al. (2016). 


\subsection{Correlation Analysis}

The correlations of all variables are presented in Table 4.2 to determine the correlation between the CCC and its components (ICP, RCP and PCP), and ROA. Based on the correlation matrix, as expected, CCC is significantly correlated with ICP, RCP and PCP; and it also significantly correlated with the control variables, except sales growth (SG). $\mathrm{CCC}$ is also not significantly correlated with ROA. The strongest correlation recorded is between PCP and DR, 0.769 , which is still below $90 \%$ level, indicating that there is no problem of multicollinearity among the variables in the study. This is further reinforced by the variance inflation factor (VIF) test which shows that the VIF for all the variables ranges from 1.1 to 4.4 , indicating no multicollinearity. Meanwhile, the Durbin-Watson statistic is 2.03 , showing that there is no problem of autocorrelation.

Table 4.2. Correlation Matrix

\begin{tabular}{|c|c|c|c|c|c|c|c|c|}
\hline & ROA & CCC & ICP & RCP & PCP & SIZE & SG & DR \\
\hline$\overline{\mathrm{ROA}}$ & 1 & -.078 & -.053 & .040 & $.276^{*}$ & -.103 & .027 & $.447^{*}$ \\
\hline CCC & & 1 & $.542^{*}$ & $.461^{*}$ & $-.321^{*}$ & $169^{* * *}$ & .090 & $-.267^{*}$ \\
\hline ICP & & & 1 & $.545^{\star}$ & $.414^{*}$ & .062 & .127 & $.296^{*}$ \\
\hline $\mathrm{RCP}$ & & & & 1 & $.304^{*}$ & -.060 & $.391^{*}$ & $.307^{*}$ \\
\hline PCP & & & & & 1 & $-.234^{* *}$ & .034 & $.769^{*}$ \\
\hline SIZE & & & & & & 1 & -.059 & -.129 \\
\hline SG & & & & & & & 1 & .000 \\
\hline DR & & & & & & & & 1 \\
\hline
\end{tabular}

*. Significant correlation at 0.01 level (2-tailed).

**. Significant correlation at 0.05 level (2-tailed)

***. Significant correlation at 0.1 level (2-tailed)

\subsection{Regression Analysis}

The F-statistics is significant, showing that the model is adequate for analysis and the $\mathrm{R}^{2}$ of the regression is $33.7 \%$, showing that on average, the independent variables can explain $33.7 \%$ of the variation in the ROA. The variables CCC and DR are positively and significantly related with ROA. This result is consistent with Sin et al. (2017), Bulin et al. (2016), Ademola (2014), Gill et al. (2011), Ali (2011) and Sharma and Kumar (2011). However, it is not consistent with Gul et al. 2013, Dong and Su (2010), Zariyawati et al. (2009), and Deloof (2003), whose studies reveal that CCC has a negative relationship with firm profitability.

Table 4.4. Regression results of the relationship between working capital management and profitability.

\begin{tabular}{lllll}
\hline Variable & Coefficient & Std. Error & T-Statistic & Prob. \\
\hline C & -7.031 & 6.391 & -1.100 & .274 \\
CCC & 0.03939 & .011 & 3.456 & $.001^{*}$ \\
ICP & -0.028 & .008 & -3.426 & $.001^{*}$ \\
RCP & -.013 & .006 & -2.023 & $.046^{* *}$ \\
PCP & .010 & .007 & 1.466 & .146 \\
SIZE & -.731 & 2.147 & -.340 & .734 \\
SG & .035 & .025 & 1.390 & .168 \\
DR & .222 & .049 & 4.475 & $.000^{*}$ \\
\hline
\end{tabular}

${ }^{*}$ Note: R-squared 0.337; Adjusted R - squared 0.283; Prob (F-statistic) 0.000

The variable ICP is negatively and significantly related to ROA, implying that the performance of firms becomes higher when the number of days of inventory is lower. This result contradicts those by Soekhoe (2012), Uremadu et al. (2012), Sharma and Kumar (2011), and Mathuva (2010). However, it is consistent with Deloof (2003), Albdwy et al. 
(2014), Gul et al. (2013), Dinku (2013), Mansoori \& Muhammad (2012), Saghir (2011), and Garcia et al. (2007).

The variable RCP is positively and significantly related with ROA, and this is consistent with the findings in Deloof (2003), Wasiuzzaman (2015), Sin et al. (2017), Ademola (2014), Ali (2011), and Lazaridis and Tryfonidis (2006). However, it is not consistent with the findings in Abuzayed (2012), and Falope and Ajilore (2009). The variable PCP is not significantly related with ROA, similar to the findings reported in Sin et al. (2017), Yunos et al. (2015), Ademola (2014), Anojan (2013), and Gill, Biger and Mathur (2010). Among the three control variables, only sales growth is significantly related to ROA, and it shows a positive relationship.

\section{CONCLUSION}

The impact of working capital management on the profitability of 94 listed Bumiputeracontrolled companies in Malaysia from 2006 to 2015 is investigated. Return on Assets is employed as the dependent variable, while the independent variables are cash conversion cycle, number of days of inventory, number of days of account receivable, and number of days of account payable. Three control variables, namely, firm size, growth in sales, and debt ratio, are also included.

The CCC is found to have a significant positive relationship with ROA, showing that CCC can be optimised to boost profitability. ICP is negatively associated with ROA, indicating that on average, the companies in the sample of the study are maintaining a low cost of storage to obtain higher profits. RCP is negatively related with ROA, indicating that companies will be more profitable if they speed up the process of collecting the account receivables. PCP is not significantly related to ROA. For the control variables, only sales growth (SG) is significantly related to ROA.

In general, when firms have low working capital, they tend to record higher return on assets. Based on the trade-off theory, profitability and liquidity of firms should be balanced. The importance of cash as a sustainable financial health indicator is not surprising given its significant role in business since the business must run efficiently and profitably. On the contrary, too much concentration on liquidity will affect profitability. Therefore, managers must be diligent in achieving the desired trade-off between liquidity and profitability to maximise the firm value. Furthermore, small firms should focus more on working capital management as they may have limited access to funding, and less efficient of financial prediction.

In general, consistent with various findings, Bumiputera listed companies are relatively less efficient in managing their assets. Therefore, it is recommended that policymakers and regulators reexamine specific relevant policies and incentives in order to improve the financial performance of Bumiputra PLCs in Malaysia. Future studies may want to compare between Bumiputera-controlled companies against non-Bumiputeracontrolled companies in WCM and also other aspects such as capital structure and also long-term debt management.

\section{REFERENCES}

Abuzayed, B. (2012). Working capital management and firms' performance in emerging markets: the case of Jordan. International Journal of Managerial Finance, 8(2), 155-179.

Ademola, O. J. (2014). Working Capital Management and Profitability of Selected quoted food and beverages manufacturing firms in Nigeria. European Journal of Accounting Auditing and Finance Research, 2(3), 10-21.

Akinlo, O., \& Olufisayo, O. (2011). The Effect of Working Capital on Profitability of Firms in Nigeria: 
Evidence from General Method of Moments (GMM). Asian Journal of Business and Management Sciences, 1(2), 130-135. Retrieved from http://www.ajbms.org

Albdwy, F., Shah, M., \& Salman, S. (2014). Impact of working capital management on the profitability of Shariah-Compliant and non-Shariah firms: The Case of Malaysia. Capital Market Review, 22, 41-58.

Ali, S. (2011). Working Capital Management and the Profitability of the Manufacturing Sector: A Case Study of Pakistan's Textile Industry. The Lahore Journal of Economics, 16(2), 141-178.

Aminudin, N. A. (2000). Corporate Performance and Ownership Structure: A Comparative Analysis Between Bumiputera and Non-Bumiputera Controlled Companies (Master thesis). Retrieved from University of Malaya Students Repository

Anojan, V., Arulalan, N., \& Nimalathasan, B. (2013). Working Capital Management and Its Impact on Profitability: A Study of Selected Listed Beverage, Food and Tobacco Companies in Colombo Stock Exchange, Sri Lanka Abstract: The International Journal of Business \& Management, 1(2), 10-17.

Baveld, M. (2012). Impact of Working Capital Management on the Profitability of Public Listed Firms in the Netherlands during the Financial Crisis. Retrieved from University of Twente Student Thesis.

Bottazzi, G., Dosi, G., Lippi, M., Pammolli, F., \& Riccaboni, M. (2001). Innovation and corporate growth in the evolution of the drug industry. International Journal of Industrial Organization, 19(7), 1161-1187. Retrieved from https://pdfs.semanticscholar.org

Bulin, S., Basit, A., \& Muhammad Hamza, S. (2016). Impact of Working Capital Management on Firm' S Profitability. International Journal of Accounting and Business Management, 4(2). Retrieved from http://www.ftms.edu.my

Charitou, M. S., Elfani, M., \& Lois, P. (2010). The relationship between working capital efficiency and profitability. Journal of Business \& Economics Research, 8(12). doi: https://doi.org/10.19030/jber.v8i12.782

Ching, H. Y., Gerab, F., \& Novazzi, A. (2011). Relationship Between Working Capital Management and Profitability in Brazilian Listed Companies. Journal of Global Business \& Economics, 3(1), 74-86. Retrieved from https://www.researchgate.net

Dong, H. P., \& Su, J. (2010). The Relationship between Working Capital Management and Profitability: A Vietnam Case. International Research Journal of Finance and Economics, (49). doi: https://doi.org/10.1017/CBO9781107415324.004

Deloof, M. (2003). Does working capital management affects the profitability of Belgian firms? Journal of Business Finance and Accounting, 30(3), 573-587. doi: https://doi.org/10.1111/1468-5957.00008

Dev, P., George, S. V., \& Ariff, M. (2006). Government Public Policy, Regulatory Intervention, and Their Impact on IPO Underpricing: The Case of Malaysian IPOs. Journal of Small Business Management, 44(1), 81-98.

Dittmar, A., Mahrt-Smith, J., \& Servaes, H. (2002). Corporate Liquidity. London: Centre for Economic Policy Research.

Falope, O. I., \& Ajilore, O. T. (2009). Working Capital Management and Corporate Profitability: Evidence from Panel Data Analysis of Selected Quoted Companies in Nigeria. Research Journal of Business Management, 3(3), 73-84. doi: https://doi.org/10.3923/rjbm.2009.73.84

Garcia, P. J., \& Martinez, P. (2007). Effects of working capital management on SME profitability International Journal of Managerial Finance, 3(2), 164-177. doi: https://doi.org/10.1108/17439130710738718

Gill, A., Biger, N., Mathur, N., Palmer, S., Street, W. H., \& Vb-k, B. C. (2010). The Relationship Between Working Capital Management And Profitability : Evidence From The United States. Business and Economics Journal, 2010(1), 1-9.

Gul, S., Khan, M. B., Rehman, S. U., Khan, M. T., Khan, M., \& Khan, W. (2013). Working Capital Management and Performance of SME Sector. European Journal of Business and Management, 5(1), 60-69. doi: https://doi.org/10.5897/AJBM2013.6899

Halim, M. S., Haniff, M. S., Junoh, M. Z., \& Osman, A. (2014). Financial performance and the management issues of Bumiputera construction firms in the Malaysian construction industry. Journal of Scientific Research \& Reports, 3(9), 1190-1202. Retrieved from http://www.journalrepository.org 
Jang, S. C., \& Park, K. M. (2011). Inter-relationship between firm growth and profitability. International Journal of Hospitality Management, 30(4), 1027-1035.

Karadagli, E. C. (2012). The Effect of Working Capital Management on the Profitability of Turkish SMEs. British Journal of Economics, Finance and Management Science, 5(2), 36-44. doi: https://doi.org/10.1007/s13398-014-0173-7.2

Lazaridis, I., \& Tryfonidis, D. (2006). The relationship between working capital management and profitability of listed companies in the Athens Stock Exchange. Journal of Financial Management and Analysis, 30(76), 1-12.

Mansoori, E., \& Muhammad, J. (2012). Effect of Working capital management on the firm 's profitability: Evidence from Singapore. Interdisciplinary Journal of Contemporary Research in Business, 4(5), 472-486.

Marimuthu, M. (2010). Bumiputera-Controlled Companies: Performance Evaluation Using A NonParametric Approach. International Journal of Economics and Finance, 2(2), 178-185. doi: https://doi.org/10.5539/ijef.v2n2p178

Mathuva, D. M. (2010). The Influence of Working Capital Management Components on Corporate Profitability: A Survey on Kenyan Listed Firms. Research Journal of Business Management. doi: https://doi.org/10.3923/rjbm.2010.1.11

Mohamad, N. \& Saad, N. (2010). Working Capital Management: The Effect of Market Valuation and Profitability in Malaysia. International Journal of Business and Management, 5(11), 140147. doi: https://doi.org/10.5539/ijbm.v5n11p140

Misbah, S., Anjum, M. J., Aqdas, M. I., Marwat, N. K., \& Khan, M. A. R. (2015). The Relationship between Working Capital Management and Profitability: Evidence from Listed Companies in Kuala Lumpur Stock Exchange (KSE) Malaysia. International Journal of Information Processing \& Management, 6(1), 104. Retrieved from http://search.ebscohost.com

Nobanee, H., \& Alhajjar, M. (2014). An Optimal Cash Conversion Cycle. International Research Journal of Finance and Economics, (120). Retrieved from http://www.internationalresearchjournaloffinanceandeconomics.com

Nimalathasan, B. (2010). Working capital management and its impact on profitability: A study of selected listed manufacturing companies in Sri Lanka. Information Management, 12, 76-83.

Raheman, A., \& Nasr, M. (2007). Working capital management and profitability- case of Pakistani Firms. International Review of Business Research Papers, 3(1), 279-300. Retrieved from https://www.researchgate.net/publication/228727444

Raheman, A., Afza, T., Qayyum, A., \& Bodla, M. A. (2010). Working capital management and corporate performance of the manufacturing sector in Pakistan. International Research Journal of Finance and Economics, 47(1), 156-169.

Ray, S. (2012). Evaluating the Impact of Working Capital Management Components on Corporate Profitability: Evidence from Indian Manufacturing Firms. International Journal of Economic Practices and Theories, 2(3), 127-136.

Rimo, A., \& Panbunyuen, P. (2010). The Effect Of Company Characteristics on working Capital Management (Master thesis). Retrieved from http://www.diva-portal.org

Saghir, A., Hashmi, F. M., \& Hussain, M. N. (2011). Working Capital Management and Profitability: Evidence from Pakistan Firms. Interdisciplinary Journal of Contemporary Research In Business, 3(8), 1092-1105. doi: https://doi.org/10.1007/s40622-014-0043-3

Salim, M., \& Yadav, R. (2012). Capital Structure and Firm Performance: Evidence from Malaysian Listed Companies. Procedia - Social and Behavioral Sciences, 65(ICIBSoS), 156-166. doi: https://doi.org/10.1016/j.sbspro.2012.11.105

Sharma, A. K., \& Kumar, S. (2011). Effect of Working Capital Management on Firm Profitability. Global Business Review, 12(1), 159-173. doi: https://doi.org/10.1177/097215091001200110

Sin, H. N., Chen, Y., Tze, S. O., \& Boon, H. T. (2017). The Impact of Working Capital Management on Firm's Profitability: Evidence from Malaysian Listed Manufacturing Firms. International Journal of Economics and Financial Issues, 7(3), 662-670.

Smith, K. 1980. Profitability versus Liquidity Tradeoffs in Working Capital Management, Readings on the Management of Working Capital. New York, NY: West Publishing Company.

Soekhoe, S. (2012). The effects of working capital management on the profitability of Dutch listed firms (Master thesis). Retrieved from doi: https://doi.org/10.3846/16111699.2011.651626

Uremadu, S. O., Egbide, B.-C., \& Enyi, P. E. (2012). Working Capital Management, Liquidity and 
Corporate Profitability Among Quoted Firms in Nigeria Evidence from the Productive Sector. International Journal of Academic Research in Accounting, Finance and Management Sciences, 2(1), 80-97. Retrieved from http://ideas.repec.org/a/hur/ijaraf/v2y2012i1p8097.html

Usama, M. (2012). Working Capital Management and its Affect on the firm's Profitability and Liquidity : in other Food Sector of ( KSE ) Karachi Stock Exchange. Oman Chapter of Arabian Journal of Business and Management Review, 1(12), 62-73. Retrieved from doi: https://doi.org/10.12816/0002232

Wasiuzzaman, S. (2015). Working capital and firm value in an emerging market. International Journal of Managerial Finance, 11(1), 60-79. doi: https://doi.org/10.1108/IJMF-01-2013-0016

Wasiuzzaman, S., \& Arumugam, V. C. (2013). Determinants of Working Capital Investment: A Study of Malaysian public listed Firms. Australasian Accounting, Business and Finance Journal, 7(2), 63-83. doi: https://doi.org/10.14453/aabfj.v7i2.5

Yatim, P., Kent, P., \& Clarkson, P. (2006). Governance structures, ethnicity, and audit fees of Malaysian listed firms. Managerial Auditing Journal, 21(7), 757-782. doi: https://doi.org/10.1108/02686900610680530

Yunos, R. M., Nazaruddin, N., Ghapar, F. A., Ahmad, S. A., \& Zakaria, N. B. (2015). Working Capital Management in Malaysian Government-linked Companies. Procedia Economics and Finance, 31(15), 573-580. doi: https://doi.org/10.1016/S2212-5671(15)01203-4

Zariyawati, M. A., Annuar, M. N., \& Pui-San, N. (2016). Working Capital Management Determinants of Small and Large Firms In Malaysia. Int. Journal of Economics and Management, 10(November), 365-377. Retrieved from http://www.ijem.upm.edu.my

Zariyawati, M. A., Taufiq, H., Annuar, M. N., \& Sazali, A. (2010). Determinants of Working Capital Management: Evidence from Malaysia. Financial Theory and Engineering ICFTE 2010 International Conference on, 190-194. doi: https://doi.org/10.1109/ICFTE.2010.5499399

Zariyawati, M. A., Annuar, M. N., \& Taufiq, H. (2009). Working Capital Management and Corporate Performance: Case of Malaysia. Journal of Modern Accounting and Auditing, 5(November 2009). Retrieved from https://www.researchgate.net/publication/259704839 